\title{
THINK-PAIR-SHARE MODEL AS SOLUTION TO DEVELOP STUDENTS' CRITICAL THINKING IN ISLAMIC STUDIES: IS IT EFFECTIVE?
}

\author{
Mohammad Kurjum*, Abdul Muhid, \& Muhammad Thohir \\ State Islamic University Sunan Ampel, Indonesia \\ *e-mail: mkurjum@uinsby.ac.id
}

\begin{abstract}
One type of cooperative learning method is Think Pair Share (TPS). This study aims at examining the contribution of the TPS method in increasing students' critical thinking in Islamic studies. These research objectives have been describing the significances of the difference between learned students using TPS method and conventional method, and the effectiveness of TPS learning method. This study uses an experimental group and a control group. The sample in this study is taken by simple random sampling technique. It is a quasi-experiment with pre-test and post-tests no equivalent control group design. The population of this research are students who take courses in Islamic studies. Samples are taken randomly by taking two classes for an experimental class and a control class. The technique of collecting data has been done by tests, while the technique of data analysis used the statistical technique of $t$-test (independent and paired samples) within the application of the SPSS release 24 program. The results of the study indicate that there is a significant difference (sig .000) between groups of students who are taught by the TPS Method and conventional Method. In addition, the TPS method has also proven to be effective for teaching Islamic studies which shows a significant difference (sig .000) between the pre-test and post-test.
\end{abstract}

\section{Keywords: think pair share, Islamic studies, critical thinking}

\section{MODEL THINK-PAIR-SHARE SEBAGAI SOLUSI UNTUK MENGEMBANGKAN PEMIKIRAN KRITIS MAHASISWA DALAM STUDI ISLAM: EFEKTIFKAH?}

\begin{abstract}
Abstrak: Salah satu jenis metode pembelajaran kooperatif adalah Think Pair Share (TPS). Penelitian ini bertujuan untuk menguji kontribusi metode TPS dalam meningkatkan pemikiran kritis mahasiswa tentang materi studi Islam. Penelitian ini bertujuan untuk mendeskripsikan signifikansi perbedaan mahasiswa yang dibelajarkan dengan menggunakan metode TPS dan metode konvensional dan efektivitas pembelajaran dengan menggunakan metode TPS. Penelitian ini merupakan quasi experiment dengan desain pretes dan posttes non equivalent control group. Penelitian menggunakan satu kelompok eksperimen dan satu kelompok kontrol. Populasi penelitian ini adalah mahasiswa yang mengambil mata kuliah studi Islam. Sampel diambil dengan secara random dengan mengambil dua kelas masing-masing untuk kelompok eksperimen dan kelompok kontrol. Teknik pengumpulan dilakukan dengan tes, sedang teknik analisis data menggunakan teknik statistik uji $t$ (independent dan paired samples) dengan bantuan program SPSS release 24. Hasil penelitian menunjukkan bahwa terdapat perbedaan yang signifikan (sig .000) antara kelompok mahasiswa yang dibelajarkan dengan metode TPS dan metode konvensional. Selain itu, metode TPS juga terbukti efektif untuk pembelajaran studi Islam yang terlihat adanya perbedaan yang signifikan (sig .000) antara pretes dan postes.
\end{abstract}

\section{Kata Kunci: think pair share, studi Islam, berpikir kritis}

\section{INTRODUCTION}

In the educational world, numerous innovations concerning instructional process shall be conducted. This is because learning is a real activity carried out by lecturers to optimize the potential of students in order to achieve maximum goals, namely creating a comfortable learning atmosphere and making students think criticly and creatively (Beetlestone, 2012; Ashaari, Ismail, Puteh, Samsudin, Ismail, Kawangit, \& Ramzi, 2012). Critical thinking is one of the higher order thinking skills required. Critical thinking skills is a mental process in perceiving the world using existing knowledge (Rosidin, Kadaritna, \& Hasnunidah, 2019). Critical thinking is an important character students 
must possess. This characters must be targeted and pursued in character education programmed at a university (Marzuki \& Basariah, 2017). Instructional process also demands students to interact actively since students shall be directed and encouraged to become active learner through innovative learning method (Silberman, 2014). For this reason, learning process based on planning is necessary and shall be conducted since it is a sustainable step and can be regarded as a forerunner to the development of the capacity of students as individuals, community members and preparation as educators in the future (Idi, 2011).

In managing a learning plan, there are various approaches that need to be considered such as learning strategies, methods and techniques. In regard to this approach, renewal must be made to suit the current development. Wena (2010) stated that the use of strategies concerning learning activities is necessary since it facilitates the learning process to achieve maximum goals of learning. This can be developed in form of cooperative learning based in which it is the forerunner to achieve cooperative learning (Lee, Brown, \& Lee, 2001; Saguni, 2013; Ramadhanti \& Yanda, 2018).

Cooperative learning as one of the teaching and learning strategies is a way of teaching where students in the class are seen as groups or divided into groups. This kind of learning implies cognitive elaboration, peer collaboration (peer tutorial), and peer copying model, which ultimately leads to development in academic achievement and self-esteem, improvement in student attitudes toward colleagues, institution, lectures, lecturers, and stimulate student to learn and think (Saguni, 2013; Huda, 2013).

Besides, implementation of cooperative learning is able to speed various basic skills for instance: cognitive skill, affective skill, critical thinking, influence academic achievements and behaviours at the pri mary, secondary and tertiary educational level (Slavin, 1995). Cooperative learning situation demands cooperation among students in managing all efforts to finish the tasks. Cooperative learning demands two or more students to interact each other in achieving learning objective as a group (Wenger, 2008). It provides opportunity for students from different backgrounds to work as a team and gain respect among others. An example of this model is
Think-Pair-Share (TPS) which is introduced by Lyman (McTighe \& Lyman, 1988) kind of model is not yet applied on Islamic studies in the Islamic Universities in Indonesia.

TPS learning model is developed by Lyman (1981) from Maryland University. This model is a form of simple cooperative learning which provides student to cooperate with other students. The advantage of this technique is concerning optimization of student participation (McTighe \& Lyman, 1988). TPS is a simple technique with large benefit. It is able to develop student's ability in remembering information, discuss the information before it is presented to the other. Furthermore, TPS is also able to improve student's confidence since all students are given equal opportunity to participate in the class. TPS as the form of cooperative learning consists of three stages which are thinking, pairing, and sharing. In this model, lecturers are not seen as learning source (teacher oriented) since students are obliged to find and understand new concepts (student oriented).

TPS is a learning model which provides every student an opportunity to participate actively with other students (Lyman, 1981). Old fashioned learning model only provided one student to participate and share their understanding to other students in the class. TPS model provides at least eight times more for students to be acknowledged and participated in the class. McTighe \& Lyman (1988) argued that this model is an effective solution in creating class discussion path. It is assumed that this model need to be managed well in order to provide opportunity for students to think, respond, and interact.

Shih \& Reynolds (2015) highlighted the rare use of TPS, as a strategy under the umbrella of cooperative learning, in the contexts of second or foreign language (L2/FL). The strategy has been massively utilized in the teaching of first language (L1). In their study on the Taiwanese adult EFL students, Shih \& Reynolds then attempted to apply utilize this technique in, as they call it, their "traditional English as a Foreign Language (EFL) reading class" (p. 221). The result of the study shows that the integration of reading and think-pair-share strategy makes it more effective to enhance students' motivation. Yet this combined-strategy did not alter their perceptions on the use of their reading strategy. 
Li, Lin, \& Wu (2017) were using a TPS brainstorming model in order to investigate the effects of pre-listening activities on the L2 junior high school students' listening comprehension. They were building an advance organizer which assists students to generate their prior knowledge for doing tasks or encouraging learning. The findings reveal that the students with an advance organizer of picture brainstorming gained higher scores than those in the control group or the vocabulary brainstorming group. However, both the vocabulary brainstorming group and the control group are not successful to increase significantly in a certain level. The study whatsoever recommends the think-pairshare advance organizer activity in helping second language learners comprehend a text. It also helps them generate prior knowledge, boost confidence for the test, reduce performance anxiety, make connections with life experiences, and inspire new thoughts.

Bamiro (2015) examined the effects of TPS strategy, alongside two other strategies (i.e., guided discovery and lecture) on the achievement of senior secondary school students in chemistry in Nigeria. Within a pre-test, post-test, control group quasi-experimental design and three level treatments (i.e., guided discovery, TPS, and lecture), the statistical data revealed that students who were taught with guided discovery and think-pair-share strategies acquired significantly higher mean scores in the post-test than those in the lecture. In his thesis, Bamiro suggests TPS strategy and guided discovery to improve students' achievement in chemistry and general science.

In advance, a recent study by Cooper (2018) addresses the popularity of TPS since introduced by Lyman in 1981 which specifically used in the context of Special Education. Cooper has been modifying the original think-pair-share strategy as it originally comprises questioning in the first stage, then asking the students to write on a certain topic (think), then pair them up to discuss the answers (pair). He has been attempting to entirely reduce the role of teacher that the questions come from the students (learner-centered) rather than the teacher as in the original one. The questions were generated from students' reading before class. Afterwards, the pair and share sections are conducted as in the original strategy. The background of this modification of the "think", as Cooper stated, is that students nowadays have higher critical thinking ability that they even can come up with better questions than the teachers do. The result of his practice shows that this modification increases the students' investment in learning and doing the tasks.

TPS learning model is expected that students can develop thinking and answering skills in communication between one another, and work together to help one another in small groups. This is in accordance with the understanding of the Think-Pair-Share learning model which is that TPS is learning that gives students the opportunity to work alone and cooperate with others (Suprijono, 2013). In this case, lecturers play an important role in guiding students to carry out discussions, so that a more lively, active, creative, effective and enjoyable lecture atmosphere is created. Thus it is clear that through the TPS learning model, students can directly solve problems, understand a material in groups and help one another, make conclusions (discussions) and present in front of the class as one step in evaluating learning activities that have been carried out.

Previous research in the present study is used to describe the important role coupled with benefits of RPS model. The first research concerning RPS model that will be used is a dissertation written by Nur Efendi, where this dissertation discusses strategies in learning biology (science) required a student-centred learning paradigm rather than student-centred learning rather than teacher-centred learning (teacher-centred). Learning that applies teacher concentration is actually good, but is merely transferring information from the teacher to students, without involving students in the process of obtaining that information.

Another research that uses the concept of TPS learning model is a dissertation written by Atmaja (2012). In dissertation written by Atmaja, it was found that the success of the learning process was determined by several factors including, the learning strategy chosen by the learner and the learner's initial knowledge. Writer has verified how far the influence of 
the strategy variables, learning models and students' prior knowledge of learning outcomes. Strategies chosen in dissertation written by Atmaja are (1) TPS Cooperative Learning Model and (2) The conventional learning strategy of textbook model as an independent variable. Initial knowledge as a moderator variable, while student learning outcomes as the dependent variable.

Strategic effort in using TPS model as learning method aims to produce new ideas that come from students as the agent of change of development in numerous sectors. Information and technology are needed in maximising the potential benefits that are proposed by this model. This concept by Eric Frangenheim is called Framework for Developing the Thinking Classroom. Eric stated that learning method shall be supported and adjusted with student needs therefore students are able to apply what is called by Free Discovery Learning (concept introduced by Bruner). Collaborative Learning as part of interactive learning model stimulates the establishment of Think Pair Share (Gillies, Ashman, \& Terwel, 2008).

The purposes of this research have been describing the significances of the difference between learned students using TPS method and conventional method, and the effectiveness of TPS learning method which this learning model has never been applied or previously applied to the teaching of Islamic Studies. In addition, it is true that many graduates' students are unable to gain the ability to develop critical and creative thinking. Given the number of new students who continues to increase every year. Fluctuations in the number of students naturally affect the learning process (Learning Process). Factual conditions of new student skills in developing their mindset is still very minimal. Therefore, a strategy is needed that can help expedite the learning process of Islamic subjects at the institution.

\section{METHOD}

This research has been quasi-experimental which is the objective of the research was observing the critical thinking of students using Think-Pair-Share method. This model, however, has not been applied at the conventional class in the Islamic Universities. The research design was Pre-test and Post-test Control Group Design. The aim of the research was to know the students' critical thinking between the TPS (Experiment) class and conventional (Control) class. The first competency of both group, experimental and control group would be the same with homogeneity test of the variance of the two groups from the pre-test data of each group. Hence, these research objectives have been describing the significances of the difference between learned students using TPS Method and Conventional Method, and the effectiveness of TPS learning method as well.

The population of this research were 209 students who were studying in the third semester in three Islamic studies courses within the sample are 70 students of Study of Al-Qur'an class. The courses, however, consist of the Study of al-Qur'an, Sufism, and theology in the Islamic Civilization History Study Program (SPI) Faculty of Adab and Humanity Sunan Ampel Islamic University in Indonesia. The research subjects can be seen at Table 1 .

Table 1. The Number of Research Subject

\begin{tabular}{lcccc}
\hline Subject & Experiment Class & Control Class & Total & Note \\
\hline Theology & 41 & 40 & 81 & \\
Sufism & 31 & 35 & 66 & Samples \\
Study of al-Qur'an & $\mathbf{3 6}$ & 34 & 70 & 209 \\
Total & 108 & 101 &
\end{tabular}


The data used in this study are the students' critical thinking scores taken from the results of the pre-test and post-test by conducting a critical thinking test. 209 UIN Sunan Ampel Surabaya Indonesia students will be used as respondents. Data collection was taken from observations coupled with the distribution of questionnaires and observations to respondents experimentally. From the collection of these data will get a score of students' creative thinking obtained from the pre-test score (before conventional class learning model is applied) and the post-test score (after the TPS learning model is applied). To strengthen the research results, interviews will be conducted with 6 lecturers regarding the application of the TPS learning model. To simplify the content, the result of these, however, had not been showed in this article.

The data analysis method uses statistical test methods. After the data had been collected, the analysis prerequisite test is continued with the hypothesis test. The prerequisite tests include a normality test, using the Kolmogorov-Smirnov and Shapiro-Wilk tests, and a homogeneity test. This hypothesis test aims to determine whether the hypothesis is accepted or rejected. The analysis used to test this hypothesis is a Paired Sample t-test with a $95 \%$ confidence level. Data analysis, both prerequisites and hypothesis testing using SPSS 24 release.

The observation steps related to TPS are: (1) the lecturer divides students into groups of four and gives assignments to all groups; (2) each student thinks and does the assignment individually; (3) students pair up with one of the colleagues in the group and discuss with their partners; (4) the team mates meet again in a group of four to discuss and present what have been discussed with other group members. This situation enables students to become active coupled with provides students with an opportunity in sharing their thoughts and findings.

In this research by Ennis (1987; 2005), there are four groups of indicators of critical thinking skills, namely as follows; (1) Elementary Clarification, basic clarification is divided into three indicators namely; identifying or formulating questions, analyzing arguments, and asking and answering clarifying questions and or challenging questions. (2) Inference, the concluding phase consists of three indicators; those are making a deduction and considering the results of the deduction, making an induction and considering the results of an induction, and making and considering the value of the decision. (3) The Basis for the Decision. This stage is divided into two indicators, namely; considering the credibility of a source and observing and considering the results of observations. (4) Advanced Clarification. This stage is divided into two indicators namely; identifying terms and considering definitions and referring to assumptions that are not stated.

\section{FINDINGS AND DISCUSSIONS Findings}

After analysing the data and giving a score for each, Table 2, Table 3, and Table 4 shown the data score for the control group's pre-test experiments and control group, i.e descriptive data, results of normal data distribution test, and test of mean differences of pre-test for experimental and control group.

Table 2. Group of Descriptive Data for the Control Group's Pre-Test Experiments and Control Group

\begin{tabular}{lllccc}
\hline & Type of Method & $\boldsymbol{N}$ & Mean & Std. Deviation & Std. Error Mean \\
\hline Critical Thinking & TPS Method & 36 & 6.2778 & 1.61442 & .26907 \\
& Conventional Method & 34 & 6.3529 & 1.77324 & .30411 \\
\hline
\end{tabular}

Table 3. Results of Normal Data Distribution Test for Experimental Group and Control

\begin{tabular}{llcccccc}
\hline \multirow{2}{*}{ Type of Method } & \multicolumn{3}{c}{ Kolmogorov-Smirnov $^{\mathbf{a}}$} & \multicolumn{3}{c}{ Shapiro-Wilk } \\
\cline { 2 - 8 } & & Statistic & $\boldsymbol{d f}$ & $\boldsymbol{s i g .}$ & Statistic & $\boldsymbol{d f}$ & sig. \\
\hline Critical Thinking & TPS Method & .154 & 36 & .031 & .963 & 36 & .258 \\
& Conventional Method & .138 & 34 & .101 & .963 & 34 & .290 \\
\hline
\end{tabular}


Table 4. Test of Mean differences of Pre-Test for Experimental and Control Group

\begin{tabular}{|c|c|c|c|c|c|c|c|c|c|c|}
\hline \multicolumn{11}{|c|}{ Independent Samples Test } \\
\hline & & $\begin{array}{l}\text { Lever } \\
\text { for } \mathrm{E} \\
\text { of } \mathrm{Va}\end{array}$ & $\begin{array}{l}\text { s Test } \\
\text { lality } \\
\text { ances }\end{array}$ & \multicolumn{7}{|c|}{ t-test for Equality of Means } \\
\hline & & \multirow[t]{2}{*}{$F$} & \multirow[t]{2}{*}{ sig. } & \multirow[t]{2}{*}{$t$} & \multirow[t]{2}{*}{$d f$} & \multirow[t]{2}{*}{$\begin{array}{c}\text { sig. } \\
\text { (2-tailed) }\end{array}$} & \multirow[t]{2}{*}{$\begin{array}{c}\text { Mean } \\
\text { Difference }\end{array}$} & \multirow[t]{2}{*}{$\begin{array}{l}\text { Std. Error } \\
\text { Difference }\end{array}$} & \multicolumn{2}{|c|}{$\begin{array}{l}95 \% \text { Confidence } \\
\text { Interval of the } \\
\text { Difference }\end{array}$} \\
\hline & & & & & & & & & Lower & Upper \\
\hline \multirow[t]{2}{*}{$\begin{array}{l}\text { Critical } \\
\text { Thinking }\end{array}$} & $\begin{array}{l}\text { Equal } \\
\text { variances } \\
\text { assumed }\end{array}$ & .329 & .568 & -.186 & 68 & .853 & -.07516 & .40495 & -.88324 & .73291 \\
\hline & $\begin{array}{l}\text { Equal } \\
\text { variances } \\
\text { not assumed }\end{array}$ & & & -.185 & 66.479 & .854 & -.07516 & .40605 & -.88577 & .73544 \\
\hline
\end{tabular}

Both two group above have been stated that the distribution is normal within the score sig .258 and .290 (Shapiro-Wilk Version). Table 4 shown test of mean differences of pre-test for experimental group and control group.

The table shows that variant of two group is homogeneous (sig .568), means $>.05$. It shows that the first students' competency has not been different significantly (sig .853), therefore their competency for Experimental group and control group formerly are the same.

Besides, the descriptive post-test result for experimental group and control group, normality test and mean difference test would be shown at Table 5, 6, and 7 .

Moreover, the table shows that normality test for the data of TPS method and Conventional method had normally been proven. The examined data will be done by pre-required test that is normality test and variant homogeneity test. The result of normality based on table 5 and 6, would be applying Kolmogorov-Smirnov (1) the score data of critical thinking for pre-test post-test on both experimental group and control group would be $p>.05$. It means both data were normally distributed.

Table 5. Descriptive Data Result for Post-Test of Experimental and Control Group

\begin{tabular}{llcccc}
\hline & Type of Method & $\boldsymbol{N}$ & Mean & Std. Deviation & Std. Error Mean \\
\hline Critical & TPS Method & 36 & 12.0278 & 2.47832 & .41305 \\
Thinking & Conventional Method & 34 & 8.6176 & 2.13222 & .36567 \\
\hline
\end{tabular}

Table 6. Result of Normality in Post-test for Experimental and Control Group

\begin{tabular}{llcccccc}
\hline \multirow{2}{*}{ Type of Method } & \multicolumn{3}{c}{ Kolmogorov-Smirnov } & \multicolumn{3}{c}{ Shapiro-Wilk } \\
\cline { 2 - 7 } & & Statistic & $\boldsymbol{d f}$ & Sig. & Statistic & $\boldsymbol{d f}$ & Sig. \\
\hline Critical Thinking & TPS Method & .125 & 36 & .171 & .943 & 36 & .063 \\
& Conventional Method & .101 & 34 & $.200^{*}$ & .967 & 34 & .376 \\
\hline
\end{tabular}


Table 7. Mean Differentiated Test for Pre-test of and Post-test Experimental and Control Group Using TPS Method within Conventional Method

\begin{tabular}{|c|c|c|c|c|c|c|c|c|c|c|}
\hline \multicolumn{11}{|c|}{ Independent Samples Test } \\
\hline & & \multicolumn{4}{|c|}{$\begin{array}{l}\text { Levene's Test } \\
\text { for Equality } \\
\text { of Variances }\end{array}$} & \multicolumn{3}{|c|}{ t-test for Equality of Means } & \multirow{2}{*}{\multicolumn{2}{|c|}{$\begin{array}{l}\text { 95\% Confidence } \\
\text { Interval of the } \\
\text { Difference }\end{array}$}} \\
\hline & & \multirow[t]{2}{*}{$\boldsymbol{F}$} & \multirow[t]{2}{*}{ sig. } & \multirow[t]{2}{*}{$t$} & \multirow[t]{2}{*}{$d f$} & \multirow[t]{2}{*}{$\begin{array}{c}\text { sig. } \\
(2-\text { tailed })\end{array}$} & \multirow[t]{2}{*}{$\begin{array}{c}\text { Mean } \\
\text { Difference }\end{array}$} & \multirow[t]{2}{*}{$\begin{array}{l}\text { Std. Error } \\
\text { Difference }\end{array}$} & & \\
\hline & & & & & & & & & Lower & Upper \\
\hline \multirow[t]{2}{*}{$\begin{array}{l}\text { Critical } \\
\text { Thinking }\end{array}$} & $\begin{array}{l}\text { Equal variances } \\
\text { assumed }\end{array}$ & 1.230 & .271 & 7.960 & 68 & .000 & .000 & 4.41013 & .55405 & 5.51573 \\
\hline & $\begin{array}{l}\text { Equal variances } \\
\text { not assumed }\end{array}$ & & & 7.994 & 67.431 & .000 & .000 & 4.41013 & .55166 & 5.51112 \\
\hline
\end{tabular}

The result of the differences shows that there is difference significantly in learning Islamic studies between the experimental group and control group (sig .000). It shows that significantly there is difference between students taught by TPS model and conventional method. It means that Islamic studies learning which is using TPS has been more effective and better than conventional method. Furthermore, Paired Sample T-test result had been to know the level of critical thinking between the experimental groups using TPS model within control group which used conventional model. It means that there had been the differences between the students' critical thinking level between the group using TPS and Conventional Model. Based on the data below, it was concluded that TPS model could develop the critical thinking students level compared with the conventional group.

Table 8 shown descriptive data for pretest and post-test using tps model in the islamic studies class and Table 9 shown effectivity test for islamic studies in pre-test and posttest experimental and control group using TPS model.

Tabel 8. Descriptive Data for Pre-test and Post-test using TPS Model in the Islamic Studies Class

\begin{tabular}{llllll}
\hline & Mean & $\boldsymbol{N}$ & Std. Deviation & Std. Error Mean \\
\hline Pair 1 & Pretest Effectivity & 6.2778 & 36 & 1.61442 & .26907 \\
& Postest Effectivity & 13.0278 & 36 & 2.47832 & .41305 \\
\hline
\end{tabular}

Table 9. Effectivity Test for Islamic Studies in Pre-test and Post-test Experimental and Control Group using TPS Model

Paired Samples Test

\begin{tabular}{|c|c|c|c|c|c|c|c|c|c|}
\hline & & \multicolumn{5}{|c|}{ Paired Differences } & \multirow{3}{*}{$t$} & \multirow{3}{*}{$d f$} & \multirow{3}{*}{$\begin{array}{c}\text { sig. } \\
\text { (2-tailed) }\end{array}$} \\
\hline & & \multirow[t]{2}{*}{ Mean } & \multirow[t]{2}{*}{$\begin{array}{c}\text { Std. } \\
\text { Deviation }\end{array}$} & \multirow{2}{*}{$\begin{array}{l}\text { Std. } \\
\text { Error } \\
\text { Mean }\end{array}$} & \multicolumn{2}{|c|}{$\begin{array}{c}\text { 95\% Confidence } \\
\text { Interval of the } \\
\text { Difference } \\
\end{array}$} & & & \\
\hline & & & & & Lower & Upper & & & \\
\hline Pair 1 & $\begin{array}{l}\text { Pretest Effectivity- } \\
\text { Postest Effectivity }\end{array}$ & -6.75000 & 1.51893 & .25315 & -7.26393 & -6.23607 & -26.664 & 35 & .000 \\
\hline
\end{tabular}


The table shows that the probability value (significance) with equal variance assumed (assumed both variants are equal) $p<.05$. It can be concluded that the Think-Pair-Share learning model is very effective for developing students' critical thinking power. Hence, significantly there is differences between pre-test and posttest effectively applied for Islamic studies ( $\mathrm{sig}$ .000). It means that the students' competency in the subjects of Islamic studies has been increased on pre-and post-test.

\section{Discussion}

The result of data analysis showed that TPS learning model was more powerful in improving student's critical thinking than the conventional learning model. TPS model is part of a series of cooperative learning that is very important to be used for learning Islamic study materials and other social sciences. This learning model uses pair discussion method followed by plenary discussion. With this learning model students are trained on how to express opinions and students also learn to respect the opinions of others while still referring to the material / learning objectives. The steps of the learning model TPS are as follow: First, lecturer conveys the core material and competencies to be achieved.

Second, students are asked to think about the material/problems conveyed by the lecturer. Third, students are asked to pair up with friends next to them (groups of 2 people) and express the results of each thought. Fourth, the lecturer leads a small plenary of discussion, each group presents the results of the discussion. Fifth, depart from these activities, the lecturer directs the discussion on the subject matter and adds material that has not been disclosed by the students, and sixth, the conclusion / conclusion. This model is different from other TPS models in general, because lecturers are required to design and manage the learning process in an orderly manner, especially when this method is equipped with internet media. This proves that the implementation of this TPS learning model is really needed, especially for learning Islamic Study material.

The TPS method also makes students think and examine what has been presented by other students. If there are things that are not understood, or not in accordance with their opinions, they will present it in the discussion forum, especially at the stages called Share. Learning model of Think Pair Share used the Inductive Learning model and it is equipped with other internet and/or electrical facilities to find and explore related material needed for discussion of specific topics. So there is no time for students to think about other issues. TPS is part of a series of cooperative learning that is very important to be used for learning Islamic study materials and other social sciences.

Learning model named TPS use the pair discussion method followed by plenary discussion. With this learning model students are trained on how to express opinions and students also learn to respect the opinions of others while still referring to the material/learning objectives. The results of this study can be practically applied as learning model which can be used by lecturers in developing student's critical and creative thinking. Furthermore, this learning model will be best applied when it is supported by proper information and technology.

As explained earlier, the purpose of this study is to apply the TPS learning method to Islamic study program students at UIN Sunan Ampel Surabaya Indonesia to determine the level of critical thinking of students tested in two classes, namely the experimental class and the control class. Of the two classes, two tests will be conducted, namely pre-test (before applying the TPS learning method) and post-test (after applying the TPS learning method). Henceforth, the test results will be able to test the level of reliability of the TPS model with four indicators of the critical way of thinking delivered by Ennes. In this study conducted by looking at the way students express ideas, make conclusions, enthusiastic students and convey arguments when meeting the TPS method obtained good quality students. It can be seen from the post-test values that tend to be better when compared with the pre-test values.

The results of the above research are in line with the basics or foundation related to theories about making TPS learning designs proposed by experts including general systems theory, communication, and learning theory consisting of behavioral, cognitive, and constructive learning theories. The planning of TPS learning design applied in this study illustrates the essence of general system theory which states that the TPS model used has an integrated planning system 
and is designed to solve a problem or meet a need. While the enthusiasm of students who were respondents in this study showed the application of communication theory in the application of the TPS model used. It is in accordance with the essence of communication theory which states that learning specifically has a goal for the development of the cognitive structure of learning, which takes place continuously and can be transferred.

One contribution of communication theory in learning is demonstrated through a model of how to study communication theory including three elements, namely the sender, channel and receiver (Sagala, 2012) where in the use of the TPS model in this study includes the three elements mentioned above. While the increase in the ability of respondents in expressing opinions in group discussions and critical thinking shown in the application of the TPS model shows the relationship of the learning model with the essence of learning theory which includes theories of learning behavior, cognitive, and constructive.

The implication of this applied model would be suitable indeed, especially for whom studied about any field of instruction. Moreover, this would be very related to the instructional process in which applied the detail concerned for cooperative learning. Universities, however, would be the important institution design and develop any methodologies in teaching and learning nowadays.

The results of this study are in line with research conducted by Hetika, Farida, \& Sari (2017) who apply TPS as a method for improving student learning motivation and learning achievement. The results showed that the application of TPS Learning (TPS) Method can improve Motivation and Learning Achievement. Before implementing the action, the score obtained was $67 \%$ then in the first cycle increased to $72 \%$, and in the second cycle increased to $80 \%$. In addition, based on a questionnaire distributed to respondents, it also increased students' Learning Motivation scores where the score in the first cycle increased from $76 \%$ to $79 \%$. In addition, in the first cycle, the students 'pre-test and post-test scores increased from 68.86 to 76.71 while in the second cycle the students' pre-test and post-test scores increased from 79.86 to 84.86 .
The other research concerning TPS uses as literature reference for the present study is a research conducted by Cahyaningrum, et al. (2018) namely Peningkatan Keterampilan Menulis Argumentasi Melalui Model Think Pair Share Audiovisual pada Siswa Kelas X-10 SMA Negeri Kebak Kramat. This research aims to improve learning process quality of writing argumentation text and argumentation writing skills through the Think Pair Share model with audiovisual media of students X-10 grade SMA Negeri Kebakkramat. It is concluded that the application of Think Pair Share model with audiovisual media is able to improve learning process quality and argumentation writing skill for the tenth grade students of SMA Negeri Kebakkramat.

Similar to the research conducted was the work done by Syafí (2018) who applied the TPS method to increase the level of student activity in improving students' speaking abilities. In this research it is proven that this strategy is very suitable for increasing the active involvement of students in improving speaking skills. This increase can be seen from the number of students categorized as being actively involved from only 7 students $(29 \%)$ in the preliminary study to 20 students (78\%) from 26 at the end of the study. The improvement in students' speaking ability can be seen from the increasing number of students whose average score is 3 , from 7 students (29\%) from 24 students in the preliminary test to 17 students $(65 \%)$ from 26 students in the final test.

Furthermore, there is also research conducted by Feni Cahyani (2018) using TPS techniques to improve the performance of students' abilities in writing argumentation. The results of data analysis from the study showed that the scores of students speaking in the experimental group after they taught using TPS tended to increase. The results of data calculations show that the t-score (3.50) is higher than the t-table (1.68) with a significant standard of $5 \%$ and a level of freedom $(d f)$ of 48 . This shows that there is an increase in student scores in performance speak after applying learning with the TPS technique. Therefore, the results of the study indicate that there is a significant difference (sig .000) between groups of students who are taught by the TPS Method and conventional Method. In addition, 
the TPS method has also proven to be effective for teaching Islamic studies which shows a significant difference (sig .000) between the pretest and post-test as well.

\section{CONCLUSION}

The result of data analysis showed that TPS learning model was more powerful in improving student's critical thinking than the conventional learning model Based on the results of research conducted in 2 stages of testing (before-TPS and after-TPS), TPS model as cooperative learning is able to increase student interest in learning and able to stimulate students in reasoning power and/or critical thinking. TPS learning model can be regarded as proper solution to replace conventional model in which the conventional model is justified by students as boring coupled with not challenging model. Hence, the final results of the study indicate that there is a significant difference (sig .000) between groups of students who are taught by the TPS Method and conventional Method. In addition, the TPS method has also proven to be effective for teaching Islamic studies which shows a significant difference (sig .000) between the pretest and post-test

\section{REFFERENCES}

Ashaari, M. F., Ismail, Z., Puteh, A., Samsudin, M. A., Ismail, M., Kawangit, R., \& Ramzi, M. I. (2012). An assessment of teaching and learning methodology in Islamic studies. Procedia-Social and Behavioral Sciences, 59(October), 618626. doi:10.1016/j.sbspro.2012.09.322.

Atmaja, I. W. W. (2012). Pengaruh strategi pembelajaran kooperatif model (TPS) Think Pair Share vs konvensional model buku teks dengan pengetahuan awal berbeda terhadap hasil belajar kognitif dan afektif mata pelajaran biologi pada pebelajar SMA Negeri 1 Jember. [The effect of cooperative learning strategies TPS (Think Pair Share Model) vs conventional textbook model and prior knowledge on biological cognitive and affective learning outcomes at SMA Negeri 1 Jember]. (Dissertation, Universitas Negeri Malang). http://karya-ilmiah.um.ac.id/index.php/ disertasi/article/view/23188.
Bamiro,A. O. (2015). Effects of guided discovery and think-pair-share strategies on secondary school students' achievement in chemistry. SAGE Open, 5(1), 1-7. doi: $10.1177 / 2158244014564754$.

Beetlestone, F. (2012). Creative children, imaginative teaching (N. Yusron, Trans). Bandung: Nusa Media. (Original worked published 1998).

Cahyani, F. (2018). The Use of Think Pair Share Technique to Improve Students' Speaking Performance. Research in English and Education (READ), 3(1), 76-90, February 2018. https://pdfs.semanticscholar.org/ff 6f/74f357d686c4fd08455a7098dd1dc3d9 a4fc.pdf

Cahyaningrum, Fitria, Andayani A., Kundharu S., (2018), Peningkatan Keterampilan Menulis Argumentasi Melalui Model Think Pair Share Audiovisual pada Siswa Kelas X-10 SMA Negeri Kebak Kramat, Jurnal Pendidikan dan Kebudayaan, Vol. 3, No.1, http://dx.doi. org/10.24832\%2Fjpnk.v3i1.605.

Cooper, F. (2018). A modification of think pair share to make it more learner-centered by using student-generated questions. College Teaching, 66(1), 34. doi:10.1080/ 87567555.2017.1390438.

Ennis, R.H. (1987). A taxonomy of critical thinking dispositions and abilities. In J.B. Baron \& R.J. Sternberg (Eds.), Teaching thinking skills: Theory and practice (pp. 9-26). New York: W.H. Freeman.

Ennis, R.H. and Millman, J. (2005). Cornell critical thinking test, level $\mathrm{X}$ (Fifth Edition). Seaside, CA: The Critical Thinking Company.

Gillies, R. M., Ashman, A. F., \& Terwel, J. (Eds.). (2008). The teacher's role in implementing cooperative learning in the classroom: An introduction. New York, NY: Springer.

Hetika, H., Farida, I., \& Sari, Y. P. (2017). Think Pair Share (TPS) as method to improve 
student's learning motivation and learning achievement.Dinamika Pendidikan, 12(9), 125-135. doi:10.15294/dp.v12i2.13561.

Huda, M. (2013). Model-model pengajaran dan pembelajaran. [Teaching and learning models]. Yogyakarta: Pustaka Pelajar.

Idi, A. (2011). Sosiologi pendidikan individu, masyarakat dan pendidikan. [The sociology of individual education, society and education]. Jakarta: Rajawali Pers.

Lee, H., Brown, H. D., \& Lee, H. (2001). Teaching by principles: An interactive approach to language pedagogy (4th $\mathrm{ed}$ ). New York, NY: Longman.

Li, C.-H., Lin, W.-L., \& Wu, M.-H. (2017). The use of a "Think-Pair-Share" brainstorming advance organizer to prepare learners to listen in the L2 classroom. International Journal of Listening, 33(2), 1-14. doi:10.1 080/10904018.2017.1394193.

Lyman, F. (1981). The responsive classroom discussion. The Inclusion of All Students. In A. S. Anderson, Mainstreaming Digest (S. 109-113). College Park, MD: University of Maryland College of Education.

Marzuki, M. \& Basariah, B. (2017). The influence of problem-based learning and project citizen model in the civic education learning on student's critical thinking ability and self discipline. Cakrawala Pendidikan, 36(3), 382-400. doi:10.21831/cp.v36i3.14675.

McTighe, J., M., \& Lyman, F. T. (1988). Cueing thinking in the classroom: The promise of theory-embedded tools. Educational Leadership, 45(7), 18-24. http://www. ascd.org/.

Ramadhanti, D., \& Yanda, D. P. (2018). Understanding poetry through the use of cooperative learning model. Cakrawala Pendidikan, 37(3), 436-446. Doi:10.21831/cp.v38i3.20675.
Rosidin, U., Kadaritna, N., \& Hasnunidah, N. (2019). Can argument-driven inquiry models have impact on critical thinking skills for students with different personality types? Cakrawala Pendidikan, 38(3), 511526. doi:10.21831/cp.v38i3.24725.

Sagala, S. (2012). Konsep dan Makna Pembelajaran. Bandung: Alfabeta.

Saguni, F. (2013). Efektivitas metode problem based learning, cooperative learning tipe jigsaw, dan ceramah sebagai problem solving dalam matakuliah perencanaan pembelajaran. [The effectiveness of the problem-based learning, the jigsaw type cooperative learning, and lecturing methods as problem solving in the instructional planning course]. Cakrawala Pendidikan, 32(2), 207-219. doi:10.21831/ cp.v0i2.1478.

Shih, Y.-C., \& Reynolds, B. L. (2015). Teaching adolescents EFL by integrating Think-Pair-Share and reading teaching adolescents EFL by integrating ThinkPair-Share and reading strategy instruction: A Quasi- Experimental Study. RELC Journal, 46(3), 221-235. doi:10.1177/0033688215589886.

Silberman, M. L. (2014). Active learning: 101 cara belajar siswa aktif. [Active learning: 101 ways of active student learning]. Bandung: Nuansa Cendikia.

Slavin, R. E. (1995). Cooperative learning: Theory, research and practice ( $\left.2^{\text {nd }} \mathrm{ed}\right)$. London: Allyn \& Bacon.

Suprijono, A. (2013). Cooperative learning teori \& aplikasi PAIKEM. [Cooperative learning theory \& application of PAIKEM]. Yogyakarta: Pustaka Pelajar.

Syafii, M. L. (2018). Using the Think Pair Share strategy to increase students' active involvement and to improve their speaking ability. IJEE (Indonesian Journal of English Education), 5, 62--80. doi:http:// dx.doi.org/10.15408/ijee.v5i1.7679 
Wena, M. (2010). Strategi pembelajaran inovatif kontemporer: Suatu tinjauan konseptual operational. [Contemporary innovative learning strategies: An operational conceptual review]. Jakarta: Bumi Aksara.
Wenger, W. (2008). Beyond teaching and learning (R. Sirait, Trans). Bandung: Nuansa. Pelajar. (Original work published 1992). 